\begin{tabular}{|l|l|l|l|l|}
\hline Cuadernos de Investigación Geográfica & 2001 & $N^{\circ} 27$ & pp. 61-78 & ISSN 0211-6820 \\
\hline
\end{tabular}

(c) Universidad de La Rioja

\title{
RUNOFF GENERATION OF ABANDONED FIELDS IN THE CENTRAL EBRO BASIN. RESULTS FROM RAINFALL SIMULATION EXPERIMENTS
}

\begin{abstract}
JOHANNES B. RIES
MARGARETE LANGER

Johann Wolfgang Goethe-Universität Frankfurt am Main, Institut f. Physische Geographie, Senckenberganlage 36, D-60325 Frankfurt am Main, Germany e-mail:j.b.ries@em.uni-frankfurt.de, margarete.langer@web.de

ABSTRACT: In the semi-arid Central Ebro basin experimental rainfall simulations with a small mobile jet rainfall simulator according to Calvo et al. (1988), Lasanta et al. (1994 and 2000) were carried out on aban doned fields near María de Huerva to investigate the conditions of runoff generation and local erodibility. On the silty soils, susceptible to soil sea ling and crusting very divergent rates of runoff and erosion rates caused by water are found. On the crusted young fallow land runoff coefficients range between 20 and 95\%, erosion rates range between 9 and 460 gm-2 in the experiments. The start of runoff was recorded between the second and fifth minute. Soil surface sealing leads to a decrease in infiltration rates and a consequent increase in runoff in comparison to freshly tilled agricultural fields. On the old fallow land, values range from 0 to $76 \%$ and 0 to 78 gm-2 depending on other parameters such as slope and the activity of the edaphon. The start of runoff was recorded between the third and the fifteenth minute. A remarkable fact is that material delivery does not sig nificantly decrease with increasing vegetation cover. Only with a vegeta tion cover of over $60 \%$ does material output decrease obviously.
\end{abstract}

The runoff rates show the same order of magnitude than those recorded by Lasanta et al. (2000) in abandoned fields near Peñaflor, but the erosion rates in María de Huerva are significantly lower.

RESUMEN: En la cuenca central del Ebro se han llevado a cabo simu laciones de lluvia con el simulador móvil de Calvo et al. (1988) y Lasanta et al. (1994 and 2000) sobre campos anandonados cerca de María de Huerva para estudiar las condiciones de la generación de escorrentía y la erodibilidad. Sobre suelos limosos, susceptibles de sellado y encostramiento, se obtuvieron muy diferentes tasas de escorrentía y erosión. En barbecho joven encostrado los coeficientes de escorrentía oscilan entre 20 y $95 \%$ y las tasas de erosión entre 9 y $460 \mathrm{~g} \mathrm{m-2.} \mathrm{El} \mathrm{inicio} \mathrm{de} \mathrm{la} \mathrm{escorren-}$ tía se registró entre el segundo y el quinto minuto. El sellado superficial conduce a un descenso en las tasas de infiltración y a un aumento de la escorrentía en comparación con campos recientemente labrados. En bar bechos antiguos los valores oscilan de 0 a $76 \%$ y de 0 a $78 \mathrm{~g} \mathrm{m-2} \mathrm{depen-}$ 
diendo de otros parámetros como la pendiente y la actividad del suelo. El inicio de la escorrentía se midió entre el minuto 5 y el 15. Un hecho nota ble es que la producción de sedimento no disminuye significativamente con el aumento de la cubierta vegetal. Sólo cuando la cubierta vegetal supera el $60 \%$ la pérdida de material disminuye claramente.

Las tasas de escorrentía muestran los mismos órdenes de magnitud que las registradas por Lasanta et al. (2000) en campos abandonados cerca de Peñaflor, aunque las tasas de erosión de María de Huerva son significati vamente menores.

Key-words: Rainfall simulation, Runoff, Erosion, Abandoned fields, Fallow land, Ebro Basin.

Palabras clave: Simulación de lluvia. Escorrentía, Erosión, Campos abandonados, Barbecho, Cuenca del Ebro.

\section{Introduction}

In the research project EPRODESERT - the acronym stands for Evaluation of Processes Leading to Land Degradation and Desertification under Extensified Farming Systems in North-East Spain - the interaction of vegetation succession and geomorphodynamics in different test areas is investigated along a transect from the High Pyrenees to the Central Ebro Basin. This transect follows a strong topographic and climatic gradient from perhumid climate in a High Mountain Region to a semi-arid climate in the lowlands in front of them (Ries, Seeger and Marzolff , 1997).

This paper presents the results from rainfall simulations for determining the sitespecific erodibility of soil and runoff generation on fallow land of different ages. It explains the wide range of results by the vegetation distribution, the zoological influences of soil fauna and the role of soil crusts for runoff coefficients and soil erosion rates. It is strongly related to the paper written by Manuel Seeger in the same issue, which shows some parameters on the same test plots simulated by the soil water-model HILL-FLOW. It is also very close to the paper from Tilmann Sauer, showing how the development of soil water content can be calculated for different soils in all five test areas for daily time steps.

\section{Test Area}

The test area is situated in Val de las Lenas, an eastern tributary of the Huerva River $15 \mathrm{~km}$ South of Zaragoza (Figure 1). Geology is dominated by Miocene gypsum, marl and clay series with interbedded limestone and sandstone which form a highly dissected steep slopes of the Mesa in the test area the Plana de Zaragoza (ITME 1998). The Holocene alluvial fills which form the flat valley bottoms are up to $20 \mathrm{~m}$ thick and consist of interbedded layers of silty loam, sandy loamy silt, interrupted by discontinuous stone and gravel layers with silty sandy matrix. In this fills multi-layered colluvisols found here belong to the order of Aridisols according to USDA and are developed as Leptic Haplogypsid with short soil profiles. They carry the former and actual agricultural fields while the slopes are used for grazing. 


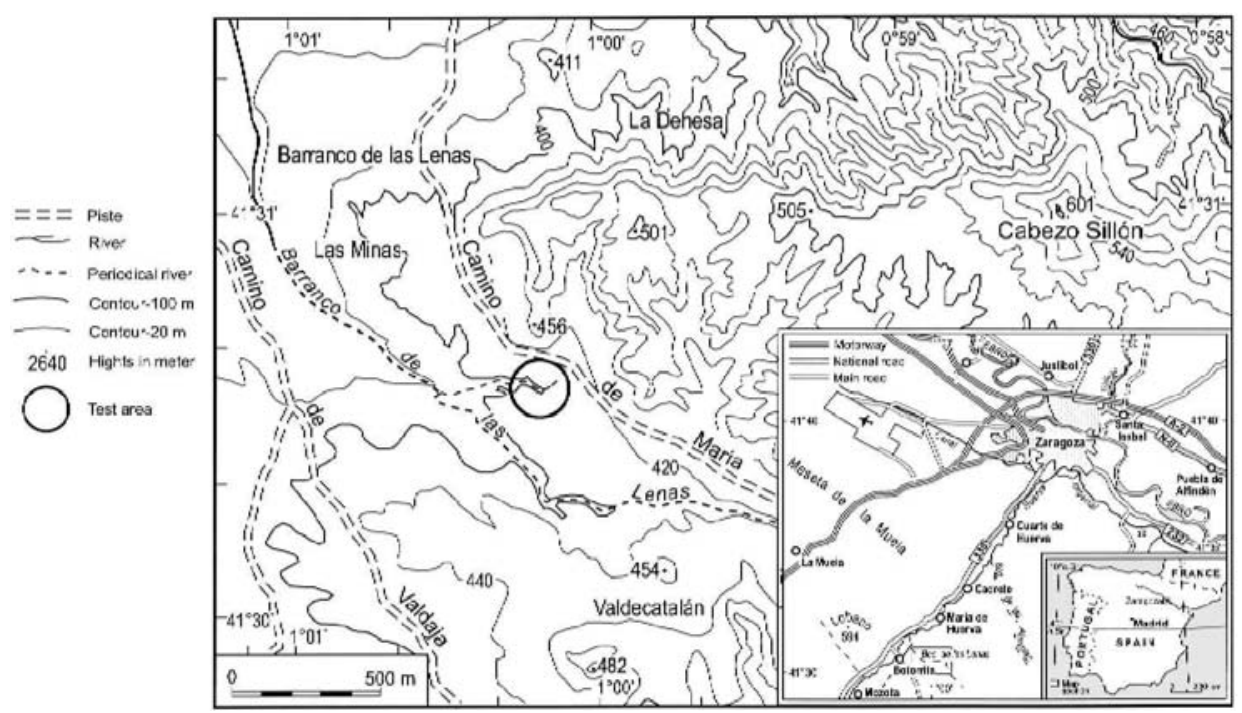

Figure 1. Test area in the Val de las Lenas Central Ebro Basin in Northeast Spain.

\section{Problems and Questions - Soil Erosion on Abandoned Fields}

Set-aside programmes of arable land have recently been supported by subsidies of the EU with the result that the number of abandoned fields has increased in the Ebro Basin since the beginning of the nineties (Figure 2). This young fallow land shows very complex fluvial-geomorphologic processes: When the former arable land is no longer ploughed, harrowed and rolled regularly, as it was usual in the traditional dry farming system, soil crusts develop and reduce the hydraulic conductivity in the upper millimeters, what causes heavily reduced local infiltration capacity. The edaphic dryness increases and the water erosion rate grows compared to that of arable land. In EPRODESERT the vegetation succession and the soil erosion are investigated on this young fallow land and are compared to the situation on older abandoned fields which are not used as agricultural fields since about 60 years (Ries et al., 2000).

On young fallow land vegetation succession is slow owing to the semi-arid climate with six arid months and a total precipitation of only $300 \mathrm{~mm}$ per year. With the rain fall in spring time a sparse therophyte vegetation mostly Hordeum murinum grows leading to low vegetation cover. During summer only dry vegetation material remains on the fields. Five years after abandonment a very low vegetation cover of about $10 \%$ can be found on the young fallow land. Thereby the vegetation succession highly depends on the tracks of the last tillage: the ridge and furrow pattern divides the fallow land up into a nanorelief which is characterised by a close coexistence of ridge areas with erosion and furrow areas with sedimentation in-between. Vegetation succession starts here because of higher soil moisture content so that therophytes may survive in dry years. After several years the first dwarf shrubs, mainly Artemisia herba alba, grow in the furrows. 


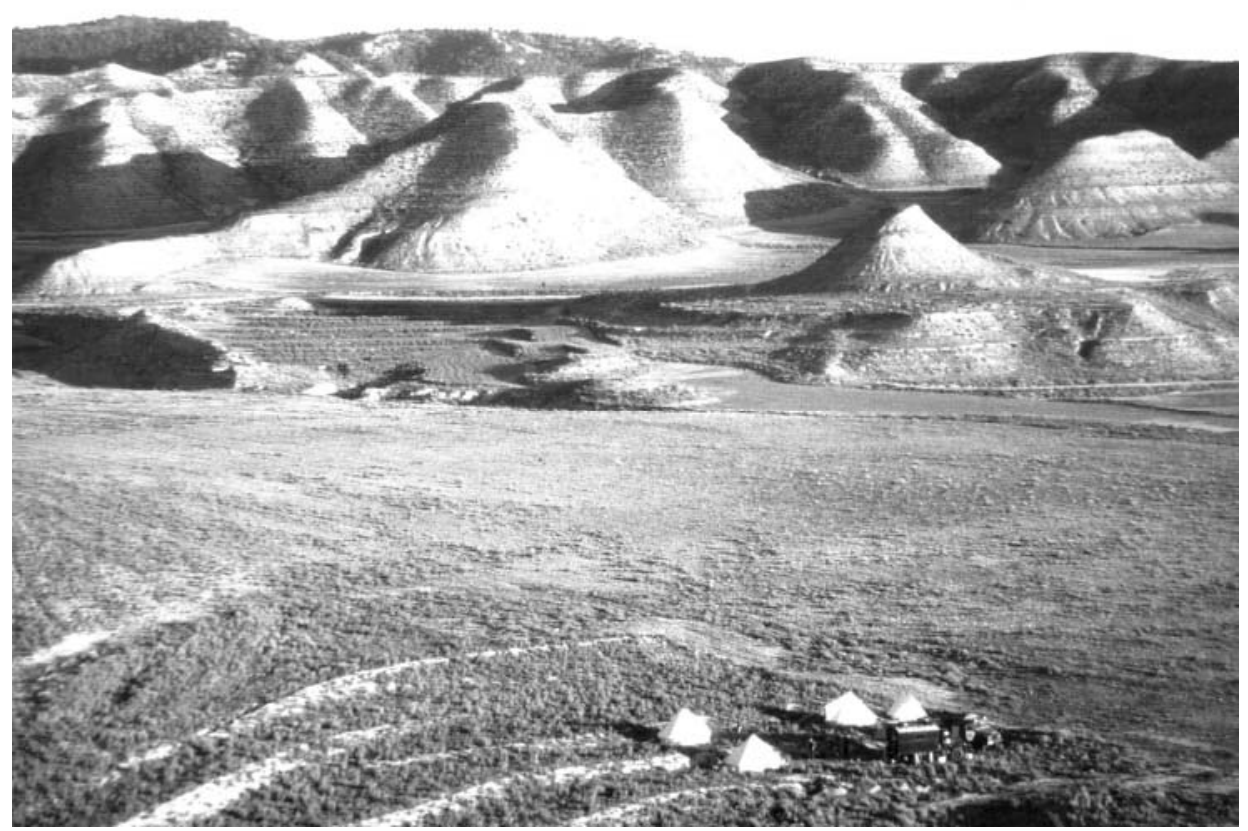

Figure 2. Abandoned fields on the flat valley bottom in the Val de las Lenas in front of the Mesa de Zaragoza

Old fallow land, too, often shows a vegetation cover of under $60 \%$ and is covered with disperse Esparto-grass vegetation, mainly Lygeum spartum, and open shrub land with Salsola vermiculata, Rosmarinus officinalis, Thymus vulgaris. Between them crusts of lichens which seal the surface often develop.

On both fields (Figure 3; soil profile 1 and 2) the Leptic Haplogypsid consists of sandy silt, the content of gypsum is with $20 \%$ and $30 \%$ respectively very high and the Corg-content with values below $0.5 \%$ low.

The pore volume of both soils is quite similar, the same we can say for the water content at permanent wilting point. The available water capacity is higher on the young fallow land (profile 1, Figure 3a) and the number of macro-pores is higher on old fallow land (profile 2, Figure 3b) because of the bioturbation of the edaphon. Due to these different situations high runoff coefficients and high erosion rates on the crusted young fallow land and lower rates on the older one are expected.

\section{Material and Methods}

111 rainfall simulations on test plots of $0.28 \mathrm{~m}^{2}$ were carried out with a small mobile nozzle type rainfall simulator. The experiments were done in situ on undisturbed surfaces from 1995 to 1998. The rainfall simulator (Figure 4) is based on the instruction of Calvo, 
Runoff generation of abandoned fields in the central Ebro basin. Results from rainfall simulation experiments

\begin{tabular}{|r|l|r|l|l|}
\hline soil profile 1 & MDH1 (1a) & aspect & $296^{\circ}$ & slope \\
\hline soil type & $\begin{array}{l}\text { Leptic Haplogypsid (USDA) } \\
\text { Hyperochric Gypsisol (WRB) }\end{array}$ & $\begin{array}{r}\text { local grid } \\
\text { altitude }\end{array}$ & $\begin{array}{l}1019 / 981 \\
416 \text { m a.s.l. }\end{array}$ \\
\hline vegetation & Hordeum murinum (0-5\%) & land use & $\begin{array}{l}\text { fallow land } \\
\text { extensive grazing }\end{array}$ \\
\hline lithology & tertiary gypsic marls & age of fallow land & 5 years \\
\hline
\end{tabular}

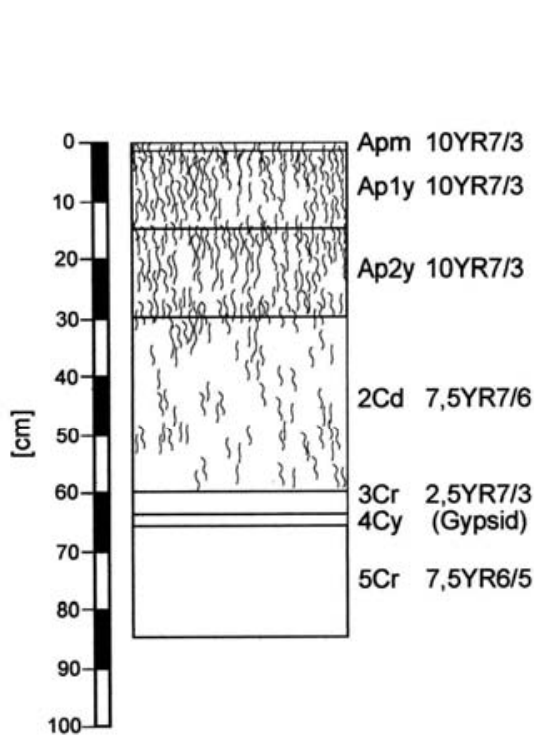

grain size distribution stones

[mass \%] [vol. \%]

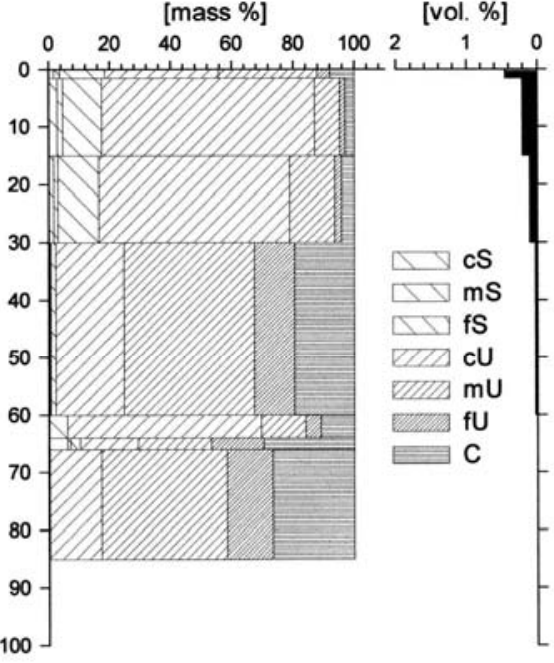

available water capacity permanent wilting point

pore size distribution

[mm]
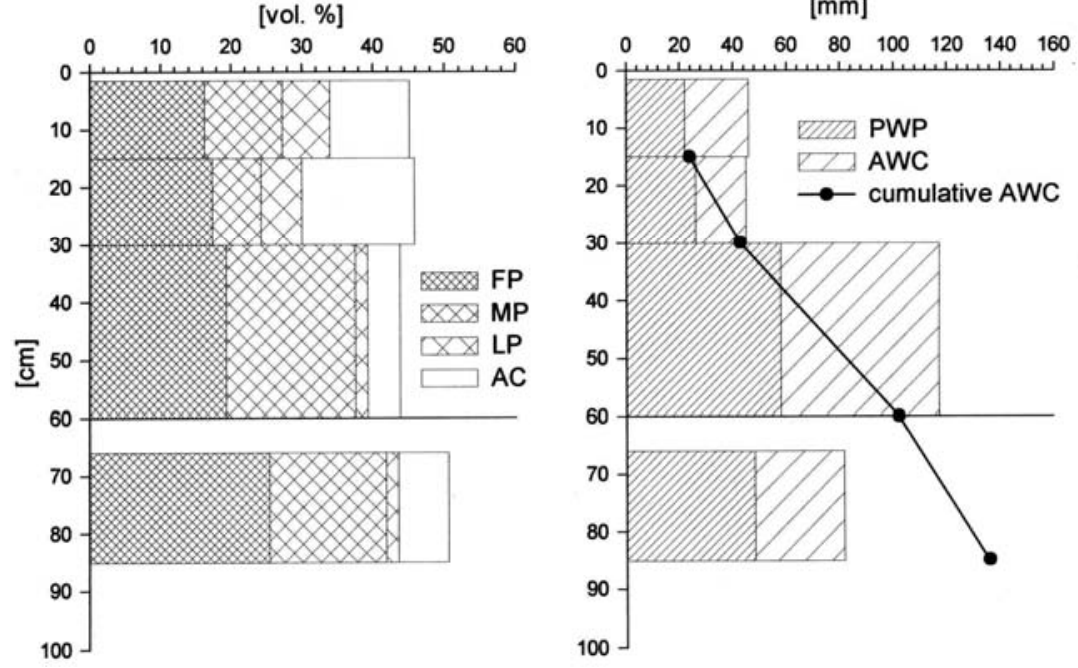

Figure $3 a$ 


\begin{tabular}{|c|c|c|c|}
\hline soil profile 2 & $\mathrm{MDH} 2(1 \mathrm{~b})$ & aspect & \begin{tabular}{ll|l}
$180^{\circ}$ & slope & $1^{\circ}$ \\
\end{tabular} \\
\hline soil type & $\begin{array}{l}\text { Leptic Haplogypsid (USDA) } \\
\text { Haplic Gypsisol (WRB) }\end{array}$ & $\begin{array}{r}\text { local grid } \\
\text { altitude }\end{array}$ & $\begin{array}{l}1039 / 1106 \\
414 \text { m a.s.I. }\end{array}$ \\
\hline vegetation & $\begin{array}{l}\text { Lygeum spartum, Artemisia herba- } \\
\text { alba }(60-90 \%)\end{array}$ & land use & $\begin{array}{l}\text { fallow land } \\
\text { extensive grazing }\end{array}$ \\
\hline lithology & holocene sediments (terraces) & age of fallow land & 65 years \\
\hline
\end{tabular}

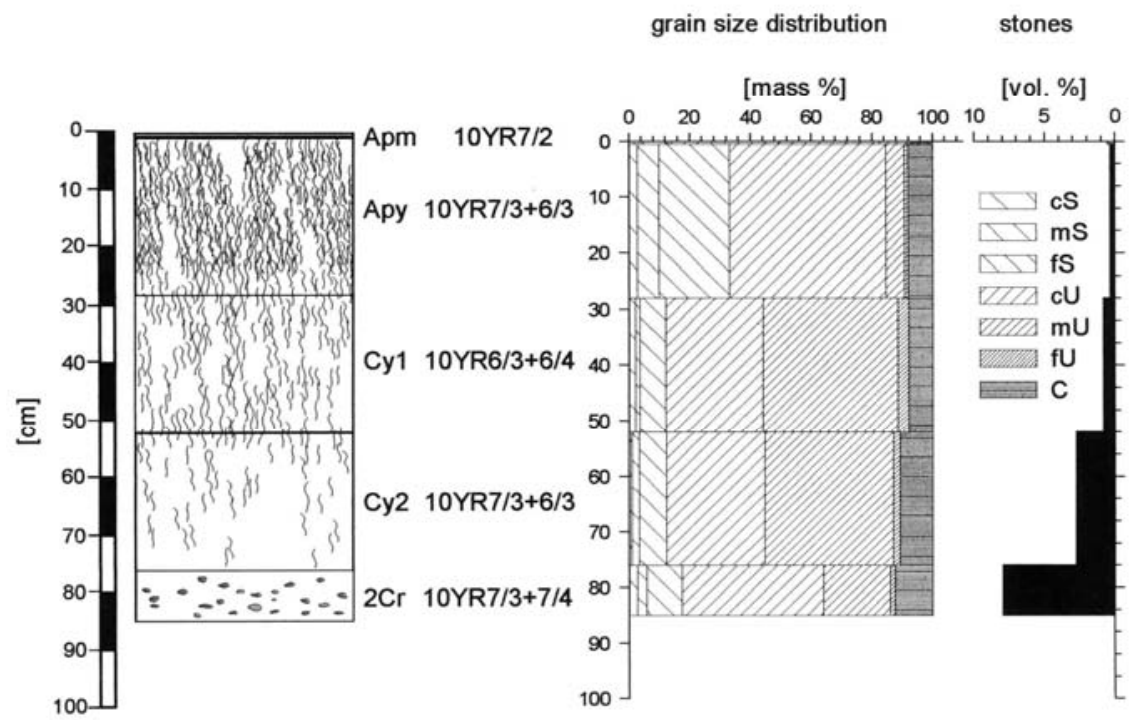

pore size distribution

available water capacity permanent wilting point
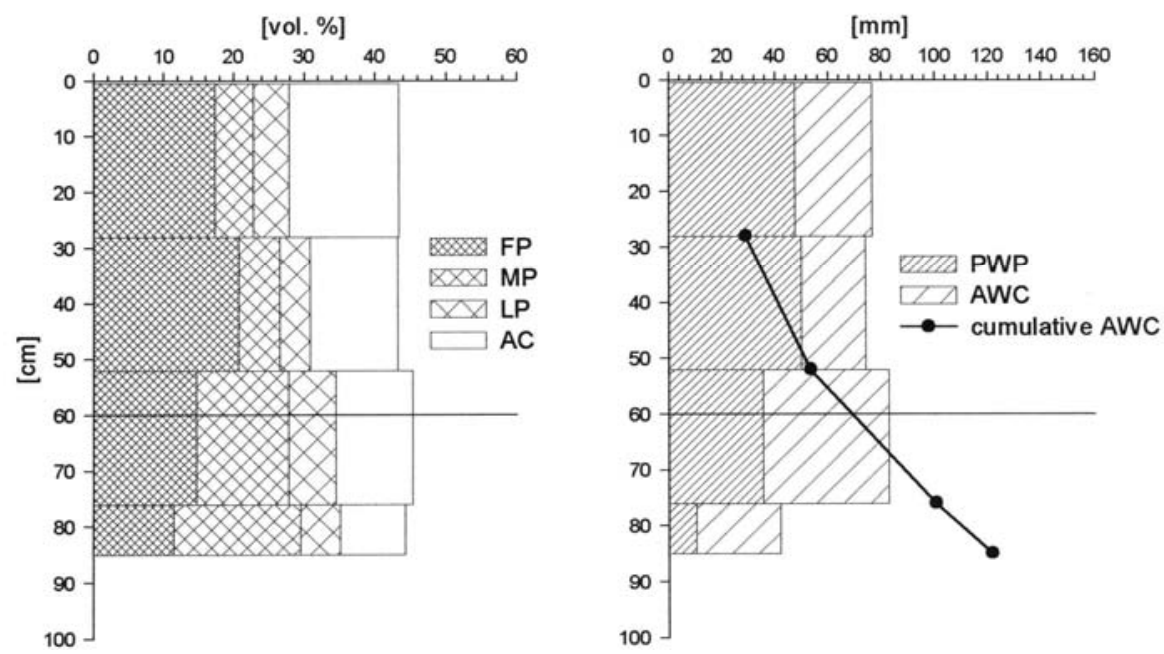

Figure 3. Soil Characteristics (horizons, grain size and pore size distribution according to German soil science nomenclature, AG Boden 1994, Bodenkundliche Kartieranleitung; pore volume and water capacity are calculated for the upper $60 \mathrm{~cm}$ ) of soil profile 1 (Figure 3a) under young fallow land and soil profile 2 (Figure $3 b$ ) under old fallow land. 


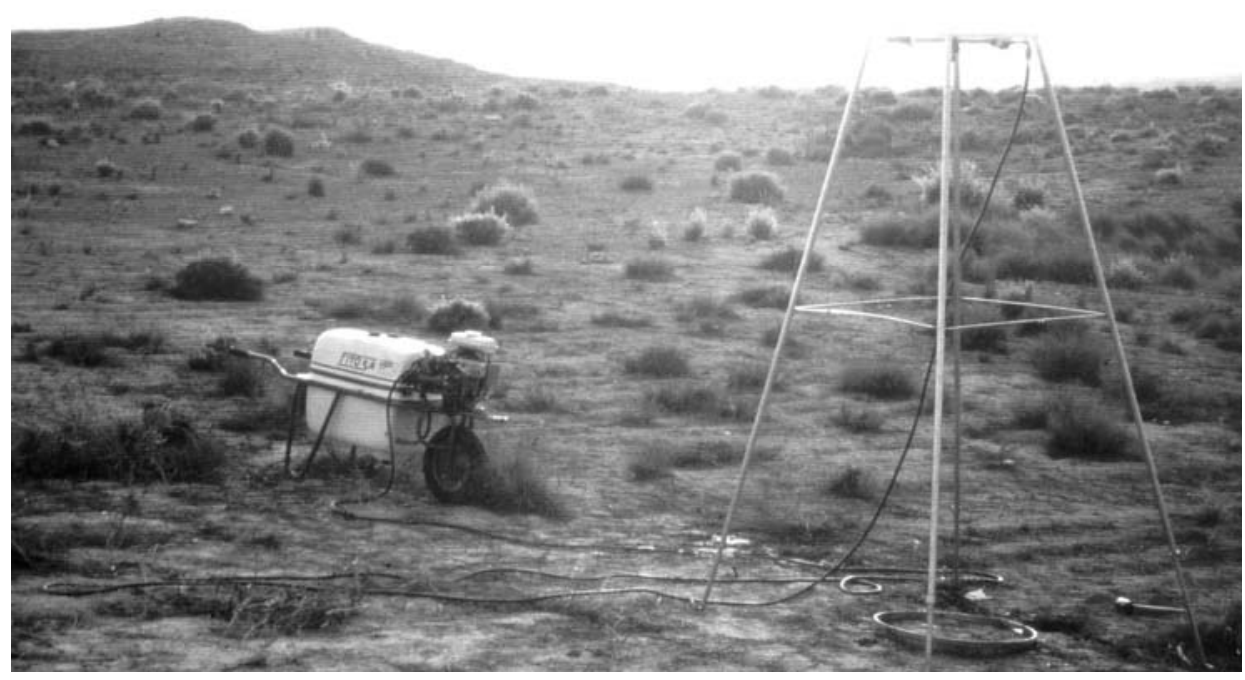

Figure 4. Small mobile rainfall simulator

et al. (1988) and Lasanta et al. (1994), who used similar nozzle type simulators for getting runoff and soil erosion rates on fallow land in the semi-arid Southeast of Spain and in the Ebro Basin. Cerdà (1995) investigated the infiltration capacity and soil erosion of degraded locations with different vegetation cover in the South of Valencia by using a similar type of system. In order to achieve good comparability of the results we decided to construct and use a small portable type of rainfall simulator which is currently employed by different research groups in Spain. The instrument consists of the following components:

1. A mobile motor-driven pump fixed together with a 100 litre water tank on a steel framework, it can be driven like a wheelbarrow.

2. A two meter high aluminium framework with telescopic and removable legs as the holder for the manometer, ventilation valve and most important the nozzle.

3. Ametal ring, $60 \mathrm{~cm}$ in diameter, $6 \mathrm{~cm}$ high with outlet and sampling sheet for the runoff.

Pump system and nozzle are connected by a rubber pipe. Water pressure and, thus, the discharge is adjusted with a simple tap at the pipe and the manometer. The nozzle is a hollow cone nozzle combined with a coarse droplet restrictor and nozzle filter which is constructed by Hardi Company for pesticide distribution (hollow cone nozzle Syntal 1553-10, $1 \mathrm{~mm}$ opening, mesh width $0.30 \mathrm{~mm}$ ). Before each simulation the rainfall intensity of 40 $\mathrm{mm}^{-1}$ is calibrated by putting a calibration plate on the fixed steel ring (Ries et al. 2000). 


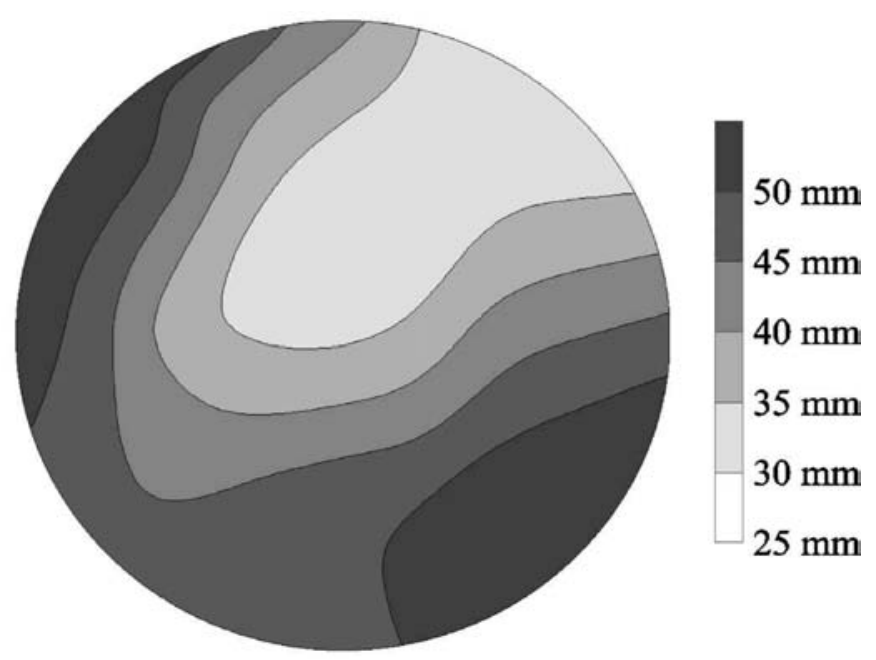

Figure 5. Rainfall distribution on the test plot [mmh-1] with $60 \mathrm{~cm}$ in diameter

The drop size distribution and the rainfall distribution on the plot of such a simulator depends mainly on the nozzle-type, water pressure, the height and the intensity of rainfall. We can say that these parameters were constant over the experiments. The rainfall distribution on the plot is not regularly, as it is normally for nozzle-type simulators with only one nozzle. The distribution shows the typical tongue-shaped divergence. The differences on the plot range between $+/-31 \%$. This seems quite high but is less than values we could find in literature about drip-screen simulators and full-cone nozzle simulators (Lascelles et al. 2000, Figure 1b, 2a; Esteves et al., 2000). More important is that this divergence is a constant methodical fault.

The drop size distribution can be seen in Figure 6, which documents the imprints in a soft Moltofill-Matrix. The small drops up to $2 \mathrm{~mm}$ diameter are overrepresented and the number of large drops over $3 \mathrm{~mm}$ is with only $3 \%$ little. The Median of the drop size is between 1 and $2 \mathrm{~mm}$, this is close to that of Cerdá (1997) with $1.58 \mathrm{~mm}$, which he measured for rainfall intensity of $40 \mathrm{~mm} \mathrm{~h}^{-1}$ for natural rainfalls in Western Mediterranean.

Tab. 1. Drop Size Distribution

\begin{tabular}{|cc|}
\hline Drop Diameter [mm] & Percentage of Drops [\%] \\
\hline $0-1$ & 48,0 \\
$1-2$ & 39,8 \\
$2-3$ & 9,2 \\
$3-4$ & 2,0 \\
$4-5$ & 1,0 \\
\hline
\end{tabular}




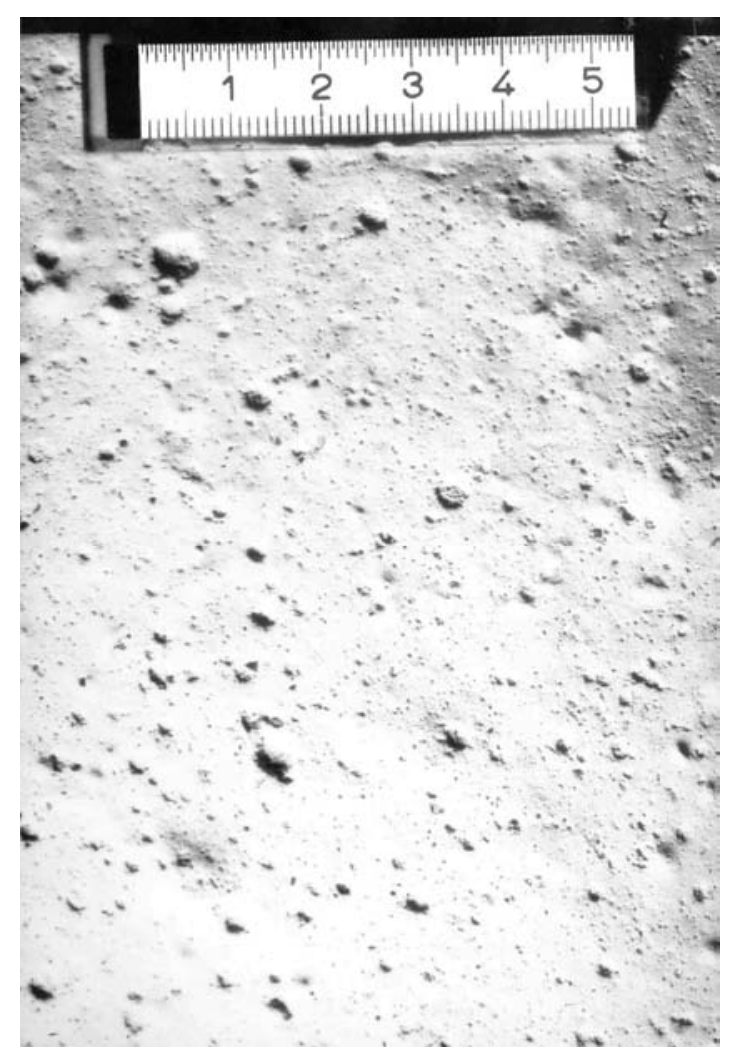

Figure 6. Drop Distribution in Moltofill-Matrix

During the experiment a plastic sheet (tarpaulin) is put over the framework in order to protect the rainfall simulation against wind and evaporation. A simulation experiment lasts for 30 minutes. During 6 intervals of 5 minutes each the total runoff is collected in plastic bottles. The amount of runoff is determined for each interval by weighing of the suspended material by filtering with Blue Ribbon and Black Ribbon filters (Schleicher \& Schuell) and weighing of filtrate. The dissolved solids are calculated from the electrical conductivity which is calibrated by evaporation residue. The concentration of suspended sediment and of solutes can be calculated.

\section{Results}

In Figure 7 runoff on the young fallow land is compared to runoff on the old fallow land. The legend shows the number of the rainfall simulation and the runoff coefficient (see Table 2). On the young fallow land most rainfall simulations show a very similar course (Figure 7a): the runoff starts between the second and the fifth minute. It rises relatively fast within the first 10 minutes. After that the runoff rate is more or less staying on the same level. The runoff coefficient ranges between 20 and $95 \%$. On the contrary 

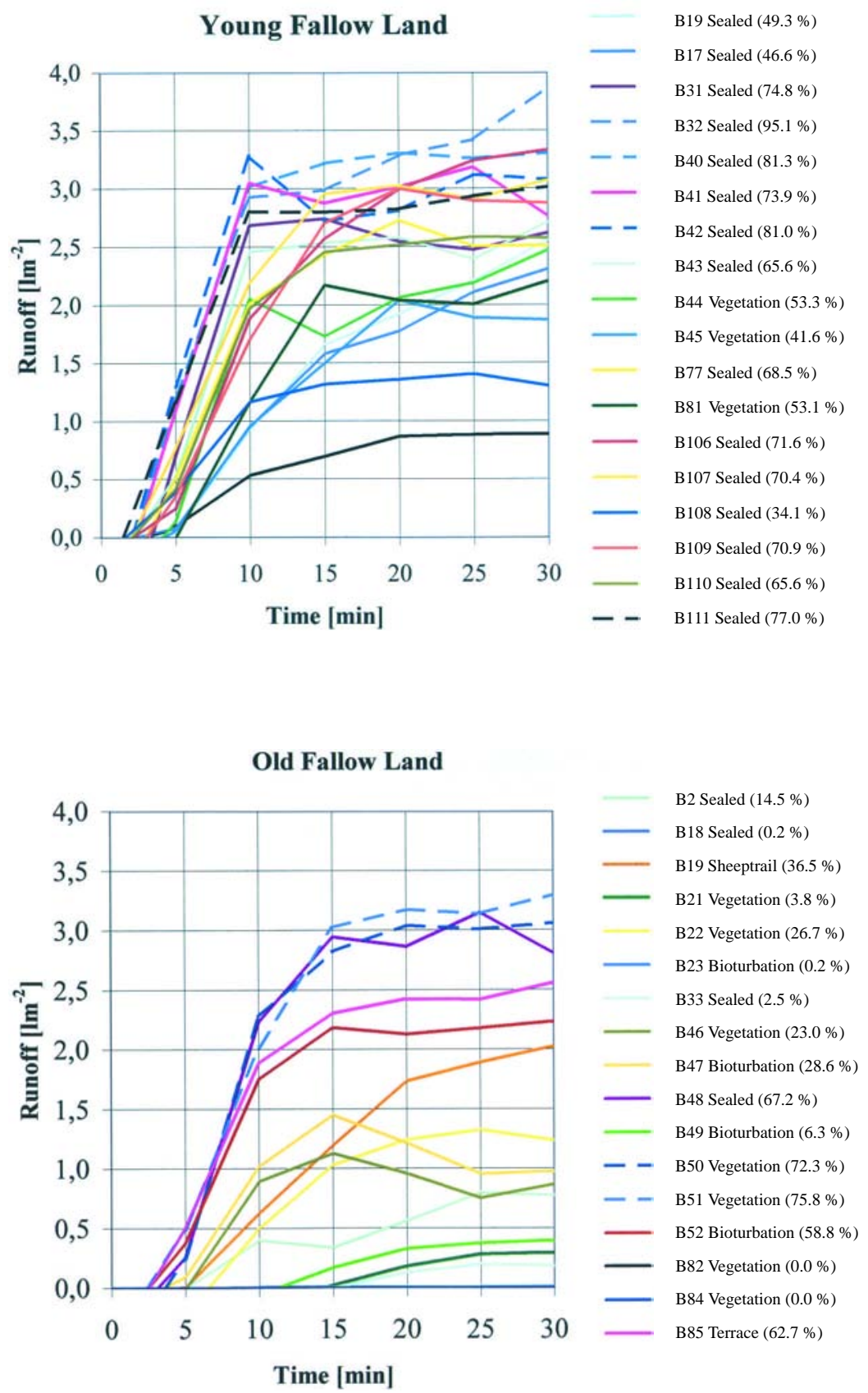

B1 Sealed $(20.0 \%)$

B19 Sealed (49.3\%)

B17 Sealed (46.6\%)

B31 Sealed (74.8\%)

B32 Sealed (95.1\%)

B40 Sealed (81.3\%)

B41 Sealed (73.9\%)

B42 Sealed (81.0\%)

B43 Sealed (65.6\%)

B44 Vegetation (53.3\%)

B45 Vegetation (41.6\%)

B77 Sealed (68.5\%)

B81 Vegetation (53.1\%)

B106 Sealed (71.6\%)

B107 Sealed (70.4\%)

B108 Sealed (34.1\%)

B109 Sealed (70.9\%)

B110 Sealed (65.6\%)

B111 Sealed (77.0\%)

Figure 7. Runoff on young (Figure 7a) and old fallow land (Figure 7b) 


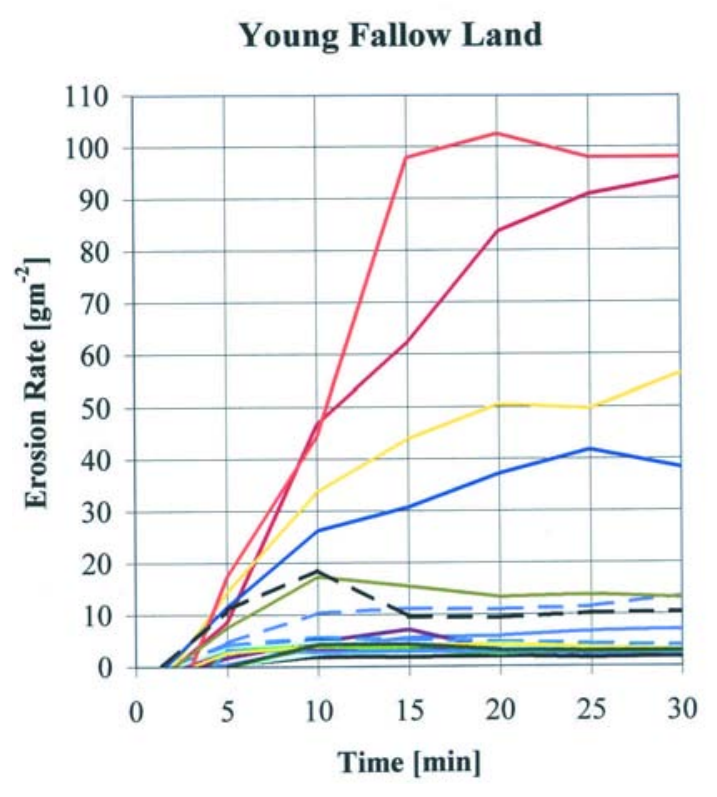

- B1 Sealed (9.05 g) B16 Sealed (13.62 g)

- B17 Sealed (29.71 g)

- B31 Sealed $(21.57 \mathrm{~g})$

— - B32 Sealed (62.53 g)

— - B40 Sealed (28.65 g)

- B41 Sealed (18.32 g)

- - B42 Sealed (20.65 g) B43 Sealed (22.67 g) B44 Vegetation (18.71 g) B45 Vegetation $(16.76 \mathrm{~g})$ B77 Sealed (21.75 g) B81 Vegetation (17.37 g) B106 Sealed (386.71 g) B107 Sealed (248.74 g) B108 Sealed (185.89 g) B109 Sealed (458.58 g) B110 Sealed $(81.10 \mathrm{~g})$ - - B111 Sealed (68.83 g)

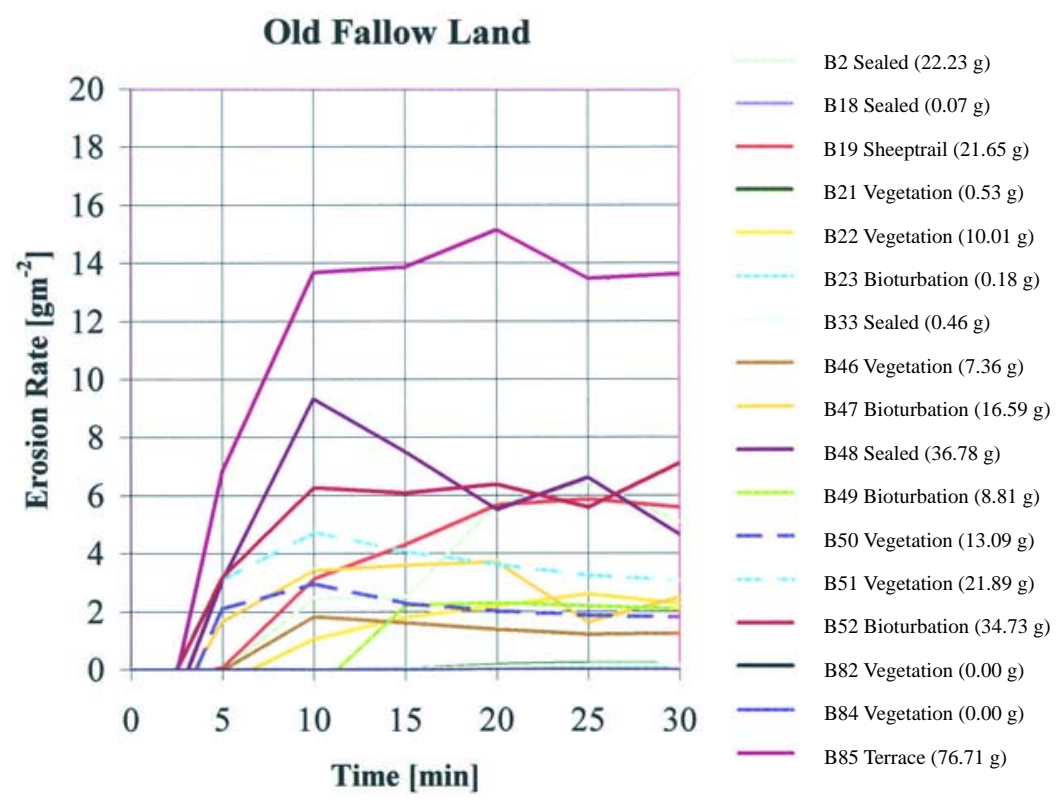

Figure 8. Erosion rate on young (Figure 8a) and old fallow land (Figure 8b) 
Table 2: Plot characteristics, parameters and results of the rainfall simulations on old and young fallow land

\begin{tabular}{|c|c|c|c|c|c|c|c|c|c|}
\hline $\begin{array}{c}\text { Rainfall } \\
\text { Simulation } \\
\text { No. }\end{array}$ & $\begin{array}{c}\text { Runoff } \\
\text { Coefficient } \\
{[\%]}\end{array}$ & $\begin{array}{c}\text { Material } \\
\text { Output } \\
{\left[\mathrm{gm}^{-2}\right]}\end{array}$ & $\begin{array}{c}\text { Suspended } \\
\text { Sediment } \\
\text { Concentration } \\
{\left[\mathrm{g} \mathrm{l}^{-1}\right]}\end{array}$ & $\begin{array}{c}\text { Start } \\
\text { Runoff } \\
{[\mathrm{min}]} \\
\end{array}$ & $\begin{array}{c}\text { Depth of } \\
\text { Infiltration } \\
{[\mathrm{cm}]}\end{array}$ & $\begin{array}{c}\text { Vegetation } \\
\text { Cover } \\
{[\%]}\end{array}$ & $\begin{array}{l}\text { Life } \\
\text { Type }\end{array}$ & $\begin{array}{c}\text { Slope } \\
{\left[{ }^{\circ}\right]} \\
\\
\end{array}$ & $\begin{array}{c}\text { Soil } \\
\text { Moisture } \\
\text { Content } \\
\text { [Mass \%] }\end{array}$ \\
\hline & & & \multicolumn{7}{|c|}{ Young fallow land } \\
\hline 1 & 20.0 & 9,05 & 14.58 & 3'40 & 3 & 2 & Thero. & 2 & 4.5 \\
\hline 16 & 49.3 & 13,62 & 1.76 & 3,57 & 4 & 3 & Thero. & 4 & 5.5 \\
\hline 17 & 46.6 & 29,71 & 3.94 & $2 ’ 26$ & 7 & 5 & - & 4 & 5.8 \\
\hline 31 & 74.8 & 21,57 & 1.67 & $3{ }^{\prime} 40$ & 10 & 10 & Thero. & 5 & 3.5 \\
\hline 32 & 95.1 & 62,53 & 3.58 & 2’02 & 4 & 5 & - & 5 & 5.8 \\
\hline 40 & 81.3 & 28,65 & 1.88 & 2’15 & 4 & 50 & Thero. & 7 & 1.8 \\
\hline 41 & 73.9 & 18,32 & 1.32 & 2,32 & 4 & 40 & Thero. & 7 & 1.7 \\
\hline 42 & 81.0 & 20,65 & 1.38 & 2’06 & 7 & 50 & Thero. & 7 & 6.4 \\
\hline 43 & 65.6 & 22,67 & 2.37 & $2 ' 10$ & 3 & 40 & Thero. & 7 & 4.8 \\
\hline 44 & 53.3 & 18,71 & 1.76 & 4'10 & 5 & 35 & Cham. & 7 & 3.6 \\
\hline 45 & 41.6 & 16,76 & 10.97 & 4'22 & 8 & 60 & Cham. & 7 & 4.3 \\
\hline 77 & 68.5 & 21,75 & 1.46 & 3'00 & n.c. & 25 & Thero. & 7 & 6.2 \\
\hline 81 & 53.2 & 17,37 & 1.51 & 5'01 & 5 & 80 & Thero. & 2 & 3.0 \\
\hline 106 & 71.6 & 386,71 & 27.94 & 2'08 & 20 & 0 & - & 2 & 10.6 \\
\hline 107 & 70.4 & 248,74 & 16.86 & 2'00 & 12 & 0 & - & 4 & 9.2 \\
\hline 108 & 34.1 & 185,89 & 27.00 & 1'58 & 7 & 0 & - & 4 & 9.3 \\
\hline 109 & 70.9 & \begin{tabular}{|l|}
458,58 \\
\end{tabular} & 35.57 & 3'02 & 3 & 0 & - & 13 & 8.7 \\
\hline 110 & 65.7 & \begin{tabular}{|l|}
81,10 \\
\end{tabular} & 8.19 & 2'04 & 5 & 0 & - & 9 & 7.5 \\
\hline \multirow[t]{2}{*}{111} & 77.0 & 68,83 & 4.94 & 1'43 & n.c. & 0 & - & 2 & n.c. \\
\hline & & & \multicolumn{7}{|c|}{ Old fallow land } \\
\hline 2 & 14.5 & 22,23 & 38.43 & $5{ }^{\prime} 00$ & 3 & 1 & Kryp. & 3 & 7.3 \\
\hline 18 & 0.2 & 0,07 & 2.75 & 6’08 & 23 & 3 & Thero. & 2 & 5.8 \\
\hline 19 & 36.5 & 21,65 & 4.52 & $4 ’ 45$ & 9 & 1 & Thero. & 10 & 5.8 \\
\hline 21 & 3.8 & 0,53 & 0.71 & $14^{\prime} 40$ & 13 & 95 & Cham. & 15 & 6.0 \\
\hline 22 & 26.7 & 10,01 & 1.91 & 6'52 & 18 & 40 & Hemikr. & 15 & 7.6 \\
\hline 23 & 0.2 & 0,18 & 5.68 & $11 ' 55$ & 18 & 25 & Hemikr. & 7 & 2.8 \\
\hline 33 & 2.5 & 0,46 & 0.90 & $15^{\prime} 04$ & 40 & 50 & Kryp. & 5 & 7.4 \\
\hline 46 & 23.0 & 7,36 & 1.61 & 5'02 & n.c. & 95 & Hemikr. & 5 & 3.2 \\
\hline 47 & 28.6 & 16,59 & 5.19 & 3'43 & 20 & 40 & Cham. & 5 & 5.5 \\
\hline 48 & 67.2 & 36,78 & 4.07 & 3'10 & 2 & 60 & Kryp. & 4 & 4.3 \\
\hline 49 & 6.3 & 8,81 & 5.22 & 11'25 & 17 & 50 & Kryp. & 6 & 6.1 \\
\hline 50 & 72.3 & 13,09 & 2.09 & 3'50 & 7 & 70 & Kryp. & 5 & 4.4 \\
\hline 51 & 75.8 & 21,89 & 2.19 & 2'30 & 9 & 80 & Thero. & 9 & 7.2 \\
\hline 52 & 58.8 & 34,73 & 3.94 & 2’48 & 6 & 40 & Kryp. & 13 & 2.3 \\
\hline 82 & 0.0 & 0,00 & 0.00 & - & 11 & 80 & Kryp. & 2 & 6.5 \\
\hline 84 & 0.0 & 0,00 & 0.00 & - & 11 & 70 & Kryp. & 2 & 6.2 \\
\hline 85 & 62.7 & 76,71 & 5.64 & 2'53 & n.c. & 3 & Kryp. & 15 & 6.6 \\
\hline
\end{tabular}

Thero. = Therophyt

Hemikr. = Hemikryptophyt

Cham. = Chamaephyt

Kryp. = Kryptogame 
the course of the runoff on the old fallow land shows a large variability (Figure 7b). The runoff starts between the third and the fifteenth minute or there is no runoff at all. On the old fallow land runoff coefficient ranges between 0 and $76 \%$.

Figure 8 shows the erosion rates of young and old fallow land. On the young fallow land the course of the sediment yield can be divided into three groups (Figure 8a): a first group with extremely high sediment delivery of about 185 to $460 \mathrm{~g} \mathrm{~m}^{-2}$, a second group with lower sediment yield of about $60 \mathrm{~g} \mathrm{~m}^{-2}$ and a third group with about 20 to $30 \mathrm{~g} \mathrm{~m}^{-2}$. Altogether erosion rate on young fallow land ranges between 9 and $460 \mathrm{~g} \mathrm{~m}^{-2}$. Erosion rates on the old fallow land show a large variability again. It ranges between 0 and $78 \mathrm{~g} \mathrm{~m}^{-2}$ (Figure $8 \mathrm{~b}$ ).

On the young fallow land soil surface sealing leads to a decrease in infiltration rates and a consequent increase in runoff in comparison to freshly tilled agricultural fields. The three different groups concerning sediment yield corresponds with the age of the soil sealing. Fresh sealed soils (which is 3 months old) receive the highest erosion rates, soil sealings of an age of about 1 year show lower sediment yield, several year old soil sealings cause the lowest but still high erosion rates. The different sediment yields can be explained by the micro topography of the plots. On young soil sealings - which develop within a short time after ploughing - the micro topography is much higher than on several year old fallow land, where the ridge and furrow pattern is much more levelled. The higher the micro topography the higher is the area of the plot and the higher is the sediment yield.

The large range of values on the old fallow land shows the variability of this site: vegetation cover with lichens, stipa gras and shrubs, sites with high activity of the edaphon, different slope angles on the terraces, sheep trails and vegetation islands. High runoff coefficients and erosion rates occur on sites with high slope angles and low vegetation cover and low soil humidity before the experiment. The highest runoff of $63 \%$ is gained at the edge of an old terrace. No runoff is gained at sites covered with lichens.

The scatter plot in Figure 9a shows the correlation between vegetation cover and runoff coefficient. The values show a large variation. We believe that the data show no relationship between vegetation cover and runoff. The right scatter plot in Figure $9 \mathrm{~b}$ shows the correlation between vegetation cover and erosion rate. With increasing vegetation cover sediment yield decreases. The Kendall correlation coefficient is -0.4 , $\mathrm{R}^{2}$ of the logarithmic fitting is 0.70 which is a quite high value. Extremely high erosion rates only occur on a vegetation cover lower than $5 \%$. But still high sediment yields of about $35 \mathrm{gm}^{-2}$ occur on a vegetation cover of $60 \%$. Only on a vegetation cover of more than $60 \%$ erosion rates are obviously lower. Nevertheless, on the old fallow land no erosion can occur on all vegetation cover. Here also other factors are important for erosion.

The runoff and erosion data of fallow land of different ages is shown in Figure 10. Putting the data in a temporal order the development of runoff and erosion rates on fal- 

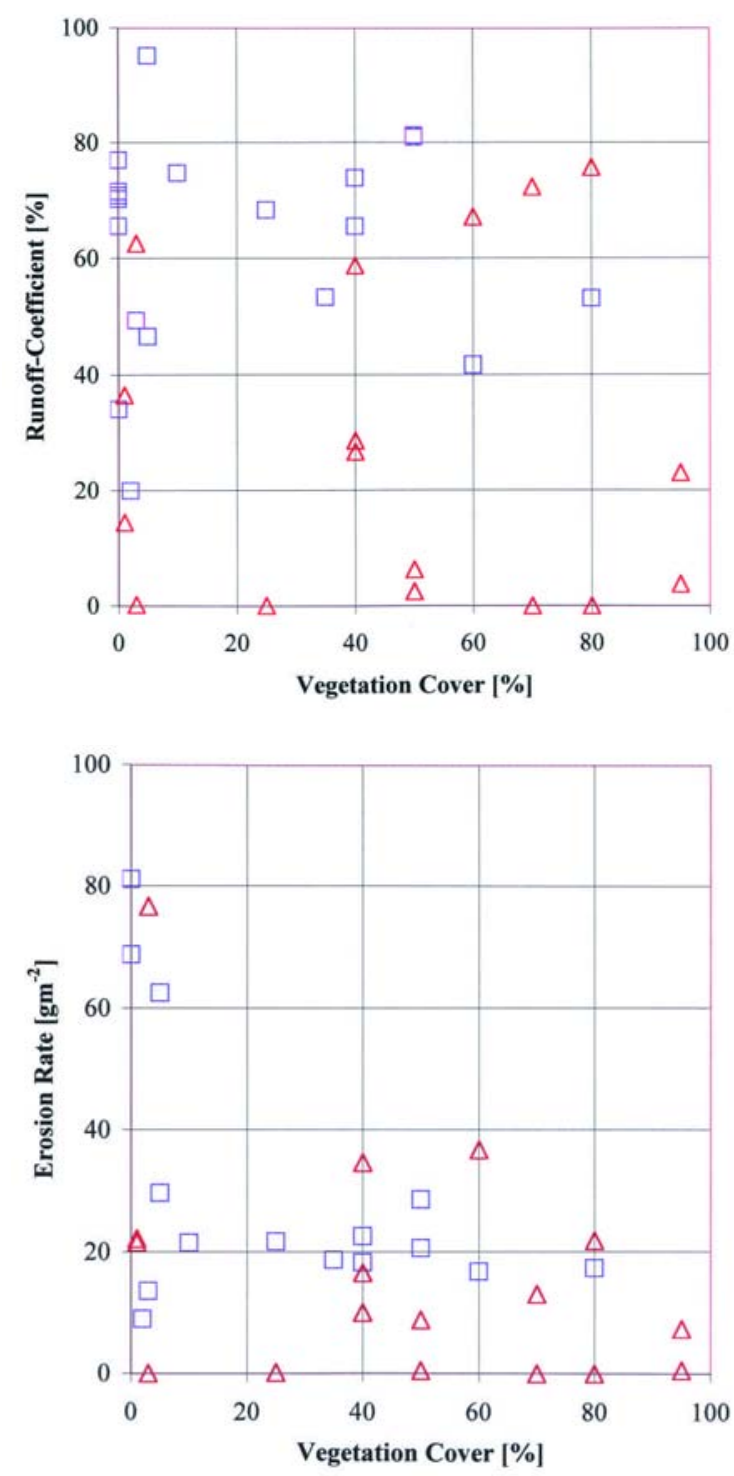

$\square$ Young Fellow Land

$\triangle$ Old Fellow Land

Figure 9. Correlation vegetation cover / runoff coefficient (Figure 9a) and vegetation cover / erosion rate (Figure 9b) from all rainfall simulations 
Runoff generation of abandoned fields in the central Ebro basin. Results from rainfall simulation experiments
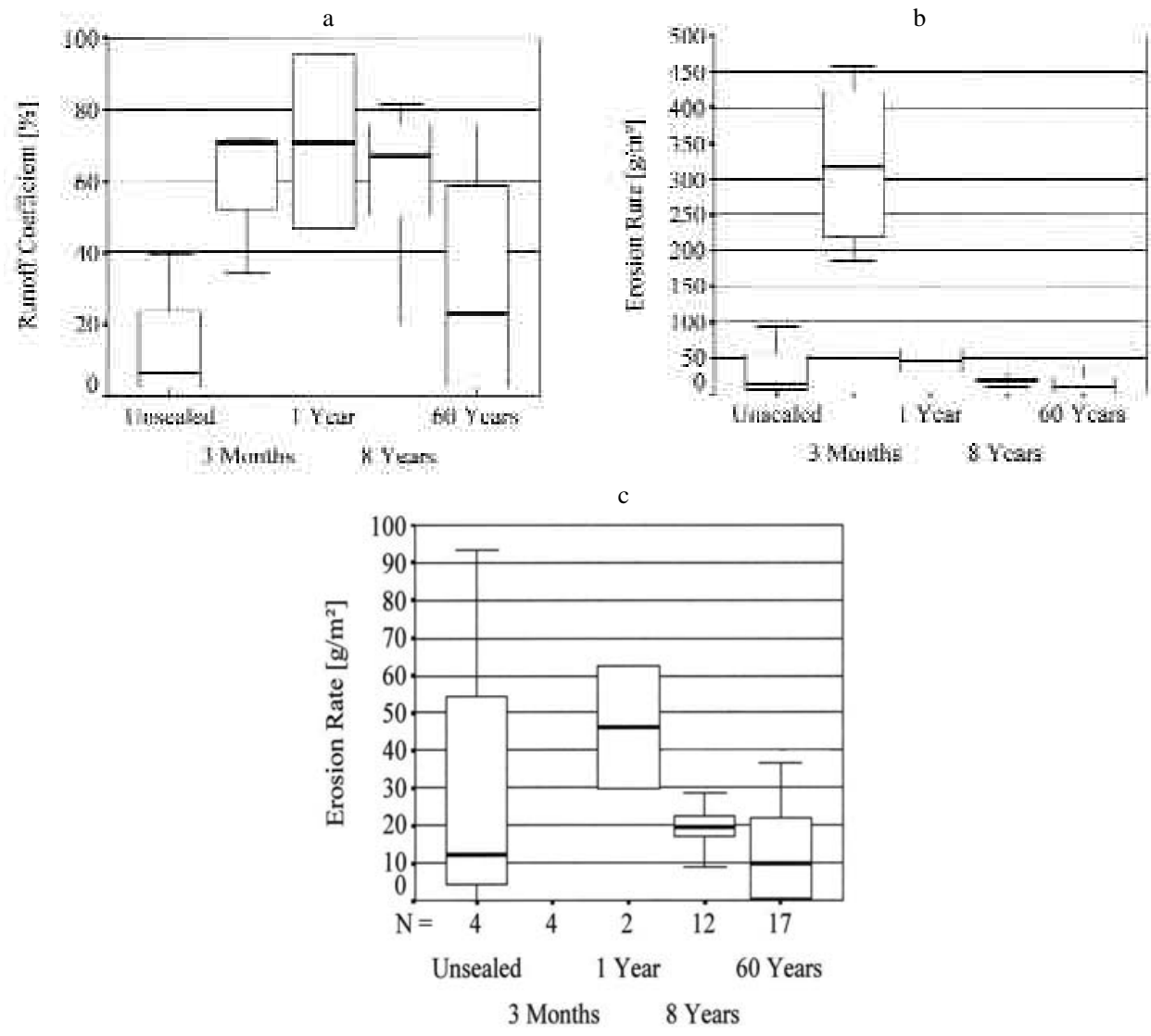

Figure 10. Temporal development of runoff (Figure 10a) and erosion rate in different scales $(10 b, 10 c)$ on fallow land of different stages.

The box plots indicate that after ploughing runoff and erosion rates are low with $6 \%$ and $12 \mathrm{~g} \mathrm{~m}^{-2}$. Only 3 months after ploughing - after 4 precipitation events with amounts of 8 to $11 \mathrm{~mm}$ - the soil is sealed so much that runoff and erosion rates increase to values of $70 \%$ and about $320 \mathrm{~g} \mathrm{~m}^{-2}$. During the following couple of years runoff is still staying on a high level of about $70 \%$. Erosion rate is decreasing to $46 \mathrm{~g} \mathrm{~m}^{-2}$ within the first year and about $20 \mathrm{~g} \mathrm{~m}^{-2}$ after 8 years. But it is still of almost the double value than immediately after ploughing. After decades of land abandonment the runoff is with $23 \%$ still significantly higher than at the beginning with $6 \%$, the erosion rate is with $10 \mathrm{~g} \mathrm{~m}^{2}$ on the same level as after ploughing.

\section{Discussion}

At first sight the high variability of runoff and erosion rates on the young fallow land seems to be surprising. But it follows from the different types of soil crusts and repre- 
sents the decreasing infiltration due to soil sealing. On the old fallow land the high variability represents the small scaled highly differentiated local characteristics of slope, vegetation pattern, soil crusts, lichens and the activity of the edaphon. As expected plots without any vegetation show the highest erosion rates. Generally the erosion rate decreases with increasing vegetation cover. But the limiting value of $30-40 \%$ vegetation cover above which soil erosion and runoff rate decrease significantly (Thornes, 1995; Dieckmann et al., 1992; Romero-Díaz et al., 1986) cannot be approved. Even on a vegetation cover of $60 \%$ high erosion rates are still possible. This has to be kept in mind when developing water shed management plans which includes reduction of erosional processes. The presented results from rainfall experiments show the same order of magnitude than experiments from the research group from the Instituto de Pirinaico de Ecología who carried out rainfall simulations with a similar machine near Peñaflor close to our investigation area in the Inner Ebro Basin (Lasanta et al., 2000). They gained a runoff coefficient of $75 \%$ which is very close to the mean value on the young fallow land with $63 \%$. The erosion rates of $40 \mathrm{~g} \mathrm{~m}^{-2}$ measured by the research group are the double of ours of $20 \mathrm{~g} \mathrm{~m}^{-2}$ (7-year old fallow land) due to the thickness of the crusts. However the most noticeable problem of land abandonment seems to be the high runoff rates during time periods of decades which diminish the soil water content. This leads to dry soil conditions in the test area during periods up to seven months causing the lack of plant available water which is the limiting factor for vegetation succession (Sauer and Ries, 2002 in this issue). Some of the measured parameters can be modelled (Seeger and Ries, 2002 in this issue) and fit very well to the field data of this investigation.

\section{Conclusions}

Regarding the results from experiments on fallow land of different ages in the central Ebro basin the following issues can be summarized:

- Land abandonment is a problem for the erosion rates $\left(320 \mathrm{~g} \mathrm{~m}^{-2}\right)$ only within the first years.

- But, for the loss of water land abandonment is a serious problem: Within the first decade it is about $70 \%$. For further 5 decades the runoff coefficient is still higher than $20 \%$ which is 4 times higher than on freshly tilled agricultural fields.

- In a region with only $300 \mathrm{~mm}$ precipitation such a water loss is a major factor for the retarded vegetation succession during a long time period.

- The huge amount of surface runoff can create linear erosion processes like rills and gullies further down.

- If the subsidies of land abandonment continues, more water will be at disposal for such processes in the future.

\section{Acknowledgements}

The work was carried out as part of the EPRODESERT Project funded by the German Research Council (No. Ri 835/1-3: «Landnutzungswandel, Erosion und Desertifikation 
in Nordostspanien»). We thank Rebecca Langhagen, Sabine Neeb, Christine Pfahls and Matthias Weise for the permission for using their data, and Christian Frevel, Dr. Irene Marzolff, Yann Matthäi, Carsten Reelfs, Tilmann Sauer and Dr. Manuel Seeger for invaluable assistance in the field. Particular thanks are due to Prof. Dr. José María García-Ruiz and Dr. Teodoro Lasanta, Instituto Pirenaico de Ecología (CSIC) for helpful comments on the methods and Prof. Dra. María Teresa Echeverría Arnedo and Prof. Dr. Juan de la Riva, Department of Geography, Zaragoza University for discussions about the sites.

\section{References}

AG Boden (1994). Bodenkundliche Kartieranleitung. Hannover, 392 S.

Calvo, A., Gisbert, J. M., Palau, E. and Romero, M. (1988). Un simulador de lluvia portátil de fácil construcción. In Sala, M. \& Gallart, F. (eds.): Métodos y Técnicas para la Medición en el Campo de Procesos Geomorfológicos. Sociedad Española de Geomorfología, Monografía No. 1, pp. 6-15, Barcelona.

Cerdà, A. (1995). Factores y variaciones espacio-temporales de la infiltración en los ecosistemas mediterráneos. Geoforma Ediciones, 151 pp., Logroño.

Cerdá, A. (1997). Rainfall drop size distribution in the western Mediterranean basin, Valéncia, Spain. Catena, 30: 169-182.

Dieckmann, H., Motzer, H., Harres, P. and Seuffert, O. (1992). Vegetation and erosion. Researches on erosion plots in Southern Sardinia. Geoöko-Plus, 3: 139-149.

ITGME (Instituto Tecnológico Geominero de España) (1998). Mapa Geológico de España, Escala 1:50 000, 383, 27-15, Madrid.

Esteves, M., Planchon, O., Lapetite, J. M., Silvera, N. \& Cadet, P. (2000). The 'EMIRE' large rainfalls simulator - design and field testing. Earth Surface Processes and Landforms, 25: 681-690.

Lasanta, T., García-Ruiz, J. M., Pérez-Rontomé, C. and Sancho-Marcén, C. (2000). Runoff and sediment yield in a semi-arid environment. The effect of land management after farmland abandonment. Catena, 38: 265-278.

Lasanta, T., Pérez Rontomé, M. C. \& García-Ruiz, J. M. (1994). Efectos hidromorfológicos de diferentes alternativas de retirada de tierras en ambientes semiáridos de la Depresión del Ebro. - In García-Ruiz, J. M. \& Lasanta, T. (eds.): Efectos Geomorfológicos del Abandono de Tierras, pp. 69-82, Zaragoza.

Lascelles, B., Favis-Mortlock, D. T., Parsons, A. J. and Guerra, A. J. T. (2000). Spatial and temporal variation in two rainfall simulators. Implications for spatially explicit rainfall simulation experiments. Earth Surface Processes and Landforms, 25: 709721.

Ries, J. B., Langer, M. and Rehberg, C. (2000). Experimental investigations on water and wind erosion on abandoned fields and arable land in the Central Ebro Basin, Aragón/Spain. Z. Geomorph. N.F., Suppl. 121: 91-108.

Ries, J. B., M. Seeger and I. Marzolff (1997). El proyecto EPRODESERT. Cambios de uso del suelo y morfodinámica en el Nordeste de España. Geographicalia, 35: 205-225. 
Romero-Díaz, M. A., López-Bermúdez, F., Thornes, J. B., Francis, C. F. and Fisher, G. C. (1986). Variability of overland flow erosion rates in a semi-arid Mediterranean environment under matorral cover, Murcia, Spain. In Harvey, A. M. \& Sala, M. (eds.): Geomorphic Processes in Environments with Strong Seasonal Contrasts, Vol. II, Geomorphic Systems. Catena, Suppl. 13: 1-11.

Sauer, T. and Ries, J. B. (2002). The Water Balance of Different Soils on Abandoned Fields along a Profile from the High Pyrenees to the Central Ebro Basin. In this issue.

Seeger, M. \& Ries, J. B. (2002). Runoff Generation on Abandoned Fields in the Central Ebro Basin - Results from Simulations.- In this issue.

Thornes, J. B. (1995). Mediterranean desertification and the vegetation cover. In Fantechi, R., Peter, D., Balabanis, P. \& Rubio, J. L. (eds.): Desertification in a European Context - Physical and Socio-Economic Aspects. Proceedings of the European School of Climatology and Natural Hazards Course, El Campello, Pueblo Acantilado, Alicante, Spain, 6-13 October 1993, Final Report, pp. 169-194, Brussels. 